\title{
Self - Care Practices of School Age Children with Nephrotic
}

\section{Syndrome}

\author{
Abu Saad FE*, Awadalla $\mathrm{NJ}^{\star *}$
}

\begin{abstract}
Background: Nephrotic syndrome is primarily a pediatric disease that is associated with high relapse rate. The nature of the disease and the side effects of medical treatments result in a great threat to children, families and society. Objective: to assess the level of self- care practices of school- aged children with Nephrotic syndrome and to identify the predictors of low self-care fuel shop Methods: A cross-sectional descriptive study was done to100 school-aged children with Nephrotic syndrome selected from the urology outpatient clinic at Mansoura university children's hospitals. Self-care practices of school age children with Nephrotic syndrome questionnaire (SCSCNSQ) Arabic version was developed by the researchers. Demographic, clinical, and self care requisites data were collected and analyzed using SPSS version 11. Results: most of the studied children had low level of self-care (self care deficit). Frequency of re-hospitalization, parents' socioeconomic standard, education and occupation were significant predictors for low self care. Regression analysis revealed that the Morerisky predictors in decreasing order are fathers' education, socioeconomic standard and frequency of hospital admission. Conclusion: Self-care level of nephrotic syndrome children should be assessed and educational training program should be provided to caregivers of children with risky predictors of low self care to improve disease outcome and minimize re-hospitalization.
\end{abstract}

Key words: Nephrotic Syndrome; School Age Children; Self Care Level; Predictors

\section{INTRODUCTION}

Nephrotic syndrome is the most hyperlipidemia and altered immunity ${ }^{(1,2)}$. Its frequent chronic renal disorder in children. prevalence in children is 15 times greater It is categorized into three groups, than in adults, with an incidence of 2 per congenital, primary and secondary, and it 100.000 children. The mortality rate of is a clinical state characterized by edema, children with nephrotic syndrome has massive proteinuria, hypoalbuminemia, decreased due to more advanced ${ }^{*}$ Departments of pediatric nursing, Faculty of Nursing, Mansoura University, Egypt ${ }^{* *}$ Public Health and Preventive Medicine, Faculty of Medicine, Mansoura University, Egypt 
treatment, however morbidity rate is still increasing. ${ }^{(3,4)}$

The nature of the disease and the side effects of medical treatments result in a great threat to children, families and society. As one type of chronic illness in children, nephrotic syndrome influences the child's physical, emotional, social and cognitive development. ${ }^{(4,5)}$ The family faces the challenge of adapting behavior patterns and activities to accommodate treatment regimens into their daily lives. ${ }^{(6)}$

Many school age children with nephrotic syndrome were hospitalized frequently with relapse of disease; the factors related to these relapses were respiratory infection, skin infection, taking steroid irregularly, and high salt diet. ${ }^{(7,8)}$ Therefore, relapse and infection among these school-age children with nephrotic syndrome might reflect either improper self-care practices of the child or inappropriate children care management by the families. ${ }^{(9,10)}$
The self-care theory proposed by Orem is a combination of three theories, theory of self care, theory of self care deficit and the theory of nursing systems. ${ }^{(11,12)}$ In the theory of self care, she explains self-care as the activities carried out by the individual to maintain their own health. There are mainly 3 types of self care requisites; universal, developmental and health deviation self care requisites. Whenever there is an inadequacy of any of these self care requisite, the person will be in need of self care or will have a deficit in self care. ${ }^{(13,14,)}$ WHO defines dependency regarding self-care activities as the inability to perform the key activities of daily life, such as maintaining personal hygiene, eating, and safety awareness that is considered one of the greatest problems. ${ }^{(15,16)}$

Good self-care practices of children with nephrotic syndrome can reduce the physical, emotional, and economic burdens of their families as well as prevent frequent 
hospitalizations and promote positive health outcomes. ${ }^{(17,18)}$

So, a study of self-care practices of school-age children with nephrotic syndrome is needed as it will contribute to the body of nursing knowledge in this area and help in identifying the predictors of low self-care.

\section{AIM OF THE STUDY}

The aim of this study is to assess the self-care practices of school- age children with nephrotic syndrome.

\section{RESEARCH QUESTION}

1- What is the level of self- care practices of school age children with nephrotic syndrome?

2- What are the predictors of low selfcare practices among children with nephrotic syndrome and their parents?

\section{SUBJECTS AND METHOD}

\section{Setting}

The study was conducted in the Urology Out patient clinic of Mansoura University Children's Hospital.

\section{Subjects}

A sample of 100 school age children with nephrotic syndrome and their parents were selected during their attendance to the outpatient clinics either for follow-up or the need for admission who met the following inclusion criteria; Both sexes, children 6-12 years of age, at least one hospital admission, and should be living with a parent or guardian.

\section{Study design}

A cross-section descriptive design was used in carrying out this study.

\section{Study tools}

All recruited patients and or their parents were subjected to the following tools:

Tool I: An interview questionnaire sheet for children with nephrotic syndrome and their parents that was developed by the researcher, it includes the following:

Part 1: Demographic characteristics of the participants and their parents, including age, gender, school grade, number of children in the family and Parents' educational levels and occupation, and socioeconomic status were 
calculated according to Fahmy and ElSherbiny. (36)

Part 2: Medical information of the participants collected from their hospital medical records and includes data about their duration of illness, number of admission and causes of all re-admissions.

Tool II: Self- care practice of school age children with Nephrotic syndrome Questionnaire (SBSCNSQ) that was based on Orem's theory of self-care as a conceptual framework adopted from Fan, $2008^{(17)}$ who used it for children with heart disease and modified by the researchers to be applicable for children with nephrotic syndrome. The SBSCNSQ consisted of three categories of self-care requisite: universal, developmental, and health deviation.

Universal self care requisites contain questions about:

- Maintenance of sufficient intake of air, water, food (as stay in fresh air, drink water at least 6 glasses per day, skip breakfast and eat scacks as candy or ice-cream ) .

- Provision of care associated with elimination process (as wash hands after using toilet).

- Balance between activity and rest time (as sleep 8-10 hours a night and do various kinds of exercise that are not vigorous).

- Prevention of hazards to child well being (as washing vegetables and fruits before eating, rinse mouth after meal, wash hands before eating, wearing suitable clothes, brushing teeth and washing hair ).

- Promotion of child functioning (as watching TV, play with friends as usual).

- Developmental self-care requisites contain questions about:

- Developmental processes (as follow friend's idea, withdraw from others during sick period, and ask for help in doing homework). 
- Adjusting to body changes (as keep contact with friends during sick period, don't go to school because of feeling embarrassed related to body change)

- Modifying life style to accommodate health state (as do all homework in remission and play sports and games with friends).

Health deviations self care contain questions about:

- Seeking and securing appropriate medical assistance (as remind your parents to take you to see doctors as scheduled, weighing at least one time a month and follow nurse advice in selection of play activities).

- Adherence to medication, diet and exercise (as take medication on time as prescribe, eat high salt food, eat food with high protein as egg, fish, and bean and select activities that you can tolerate).

- Seeking assistance when symptoms occur (as tell parents to test your urine when you have proteinuria, tell your parents if you have signs and symptoms of side effects of medication and tell your parents and teachers if you have any abnormal symptoms). (smell K)

A Likert Scale with three levels consisting of 50 items, 37 positive and 13 negative items was used. A scoring system of the positive items is 0 for never, 1 for sometimes, and 2 for always and those of the negative items are on the contrary. The range of the total score is 0 to 100 . The scores were divided using a proportional method to detect self-care level into:

Low: (self-care deficit) 0-33\%, Moderate: $33.01-66 \%$, High: $66.01-100 \%$

Among the 50 items, 22 were universal, 10 were developmental, and 18 were health deviation of self-care, this three dimensions were divided into three levels of self-care by the investigator using a proportional methods into:

Low: $\quad 0-15, \quad$ Moderate 15.01-29, 
High: 29.01-44 (for universal domain).

Low: $0-7$, Moderate 7.01-14, High: 14.01-20 (for developmental domain).

Low: $\quad$-12 Moderate 12.01-24,

High: 24.01-36 (for health deviation self-care domain).

\section{METHODS}

- A permission to conduct the study was obtained from the medical director of the hospital, the director of the outpatient clinics and physicians in the urology clinic at Mansoura University Children's Hospital.

- The medical information of the children records were reviewed to select children who met the inclusion criteria of the study.

- The questionnaire was translated into Arabic separately by two bilingual translators (the two authors). The two versions were combined and revised and then back translated into English. The translation was refined after back translation until agreement was obtained among the translators. Five bilingual experts (staff members of Public Health and Pediatric nursing, Faculties of Medicine and Nursing, Mansoura University) examined the Arabic version of the questionnaire for content and construct validity and agreed upon it.

- A pilot study was conducted on 10 children who were excluded from the study sample to test the clarity of the study tools and reliability of the Arabic version. The tool was relevant and applicable but some words had been modified. Reliability of the Arabic version was tested using Cronbach alpha test. Cronbach $\alpha$ coefficient of internal consistency was reported to be 0.84 .

- Ethical consideration: The purpose of the study was explained to the participant and their parents and a verbal approval for their cooperation and participation in the study were 
obtained.

- $\quad$ The Arabic questionnaire was read to each participant by the investigator, and then the participants completed the questionnaire independently within 30 to 45 minutes. The parents completed the demographic form within 10 to 15 minutes.

- Data were collected through 9 months starting from January to September 2009.

- Data were analyzed using SPSS (Statistical Package for Social Sciences) version 11. Demographic criteria for the children and their parents and disease characteristics were presented as number and percentage and compared using Chisquare test. Univariate analysis was performed to evaluate the influence of individual characteristics and sociodemographic data on the low self care. Significant factors predicting low self care on univariate analysis were entered into multivariate logistic regression analysis to find out the independent predictors of low self care. Odds ratio and 95\% confidence interval were calculated. $\mathrm{P} \leq 0.05$ was considered statistically significant.

\section{RESULTS}

The results of the study were divided into two parts:-

Paret I: Description of the participants:-

Table (1) shows the distribution of the studied sample according to their general characteristics, causes and duration of illness, numbers and causes of rehospitalization. More than half of children (53\%) were between 6 years to less than 8 years, (27\%) were between $10-12$ years and (20\%) between 8 years to less than 10 years, with mean age of 8.7 years \pm 2.29 . Most of children were male (58\%) and from rural areas (59\%). More than half of cases (51\%) had unknown cause of illness, while $30 \%$ of them were due to infection and only (19\%) were related to genetic causes. 
Regarding duration of illness, the numbers of hospitalization and causes of rehospitalization, $45 \%$ of cases had middle duration of illness (2-4 years), $40 \%$ of them were admitted to hospital for two times and half of them (50\%) had been re-hospitalized because of infections and relapse of the disease.

Table (2) clarifies the sociodemographic characteristics of the families of the studied children. The table reveals that $43 \%$ of the participant families had three children. Also, about half of the participants' mothers (49\%) and more than one third of the participants' fathers (39\%) were illiterate. Regarding parents' occupation, most of mothers (65\%) were house wife and most of fathers (66\%) had private work, in the form of labor work as carpenter, painter, or working in private company, office or industry. The table also shows that nearly half of the participant's families ( $47 \%$ ) had low and very low socioeconomic levels, while the numbers of the participant's families in middle and high socioeconomic levels were quiet similar $(27 \%$ and $26 \%$ ) respectively.

Part 2: Assessment of self-care practice and predictors of low self-care of the participants:

Table (3) shows the percentage distribution of self-care levels of the participants regarding their total score and three domain of self-care request, it was found that more than half of the children $(51 \%)$ had low level of self-care in relation to total score, while $(30 \%)$ had moderate and only $19 \%$ had high levels of self-care. Regarding the universal domain, it was found that $43 \%$ of children had low selfcare (self-care deficit). These deficits were more evident in eating candy and skip of breakfast (47\%), brushing teeth and washing hair $(50 \%)$, and watching TV frequently $(52 \%)$. Fifty nine percent of children had developmental self-care deficit which was more evident in having less friends after becoming sick or in hospital (45\%), never go to school and do 
homework in remission (94\%)and never play games with friends(47\%). Health deviation self-care deficit was reported in (36\%) of children in the form of eating high salt diet (48\%), testing urine for proteinuria (50\%), taking medication (43\%), detecting abnormal symptoms (40\%) . (data not shown in the table).

Table (4) Clarify the Univarete analysis for the predictors of self-care deficit among participants with nephrotic syndrome. As the table reveals that admission to hospital for 2 times increase the risk of self care deficit significantly by about four times $(\mathrm{OR}=4.42$ and $\mathrm{p}=0.009)$, this risk significantly increase up to about 15 times when the patients were admitted for four times or more ( $O R=14.67, p=0.000)$. On the other hand, there were no significant increase in the risk of self care deficit and age, gender educational class, residence, disease duration, birth order and causes of re hospitalization.
Table (5) Reveals that the risk of self-care deficit significantly increase with decreasing father and mother educational level $(O R=$ 34.36 and 33.23 and $p=0.000$ for illiterate fathers and mothers respectively). Also, the risk increase among unemployed fathers and whose working in private works $(\mathrm{OR}=6.15$, $\mathrm{p}=0.01$ and $\mathrm{OR}=8.00$ and $\mathrm{P}=0.00$ respectively) and among house wives $\mathrm{OR}=$ 6.40 and $p=0.001)$. Moreover, the risk of self care deficit significantly increase with decreasing the socioeconomic standard (OR $=32.37, p=0.000$ and $O R=4.51, p=0.03$ for low and middle levels respectively)

The results of multivariate analysis for the risk factors of self care deficits are shown in table 6. Significant independent predictors of self care deficit, in decreasing order; low socioeconomic standard (OR=36.95), four and more hospital admission $(\mathrm{OR}=34.45)$, middle socioeconomic standard (OR=12.87). Illiterate and fathers who had secondary, preparatory or primary education (OR=11.26 and 6.08 
respectively)

\section{DISCUSSION}

In this study, the school-age children with nephrotic syndrome were assessed to determine their level of self-care in relation to the three domains of self-care theory and identifying the predictors associated with low self-care (self-care deficit).

In the present study, the prevalence of nephrotic syndrome is higher among males (58\%) compared to females and this is in agreement with Huether (2002), Wilson and Winkestein $(2005)^{(19,20)}$ who mentioned that nephrotic syndrome is common among males than females. Vogt and Avner (2004) $^{(21)}$ mentioned that approximately $85 \%$ of children with nephrotic syndrome had a type of primary disease called minimal change nephrotic syndrome (MCNS) which resulted from unknown causes, this also corresponds to the results of this study as more than half of cases had unknown causes of illness.

About half of the re-hospitalized children are related to disease relapse and infections and this is in agreement with Hogg et $\mathrm{al}(2000)^{(22)}$ who stated that children maybe re-hospitalized because of edema or major infection with massive edema, proteinuria and fatigue.

Health state influences children's selfcare practices significantly as children who complained of more health symptoms performed fewer self-care practices.(23,24) Also increased frequency of relapse is associated with more frequent follow up visits at the clinic, resulting in more absenteeism from school, longer periods lost in illness, uncertainty and inactivity, isolation from peer groups and inability to catch up with academic sessions. ${ }^{(25,26)}$ In the present study more than half of schoolage children with nephrotic syndrome had low level of self-care practices in relation to the total score of self-care practice and most of them had low self-care regarding developmental domain of self-care. Also more than one third had low self-care 
regarding universal and health deviation domain.

There is no significant difference between children's age and low self-care and this come in contrary with the results of some studies that examined the effects of the children's demographic factors on selfcare behaviour and demonstrated that older children had a higher level of selfcare independence than younger children. ${ }^{(26,27)}$ Culture difference is one of the important factors that can alter children's care dependency. ${ }^{(28)}$ Primary school-age children are still according to our culture needs assistance from their parents especially during period of illness for performance of self-care activities. A study made by Wong (2007).(29) indicated that Chinese children of all ages in Hong Kong had better results in their care ability than their American counterparts.

On analyzing the predictors associated with low self-care, it was found that there was no significant relations between gender and low self-care .This is in contrary with a study conducted by Wong et al (2002). ${ }^{(30)}$ on 445 Chinese children indicated that girl's mastered self-care and communication competencies earlier than boys. Also a study conducted by Alserety(2003).(31) attributed this to the fact that the mothers of male children were much more involved in the care of their offspring than the mothers of female children, left girls under more pressure than boys to take over their self-care.

In the present study, frequent hospital admissions is associated with low self-care practice. Improper universal self-care practices and deviation in health management in relation to diet, salt restriction, fluid intake and corticosteroid side effects increase the risk of infection and relapse. Infection and relapse are constant sources of danger to hospital admission. ${ }^{(32)}$

The risk of low self care deficit increases with low educational levels. This 
could be related to the fact that low educated parents can not help their children to perform correct healthy practices. This is in agreement with Schmidt (2003).(33) who reported that parent educational levels are predictors of self-care practice of school-age children with nephrotic syndrome, if the parents have high levels of education they are more knowledgeable and capable in helping their children to perform self-care practice at a high level.

Low socioeconomic standards, parents' unemployment and private fathers' work in small workshops increase the risk of self care deficit this is in accordance with Phlermo (2002) and Lin, et al(2004)(34,35) who reported that socioeconomic standard correlates negatively with children low self care practice. Additionally, the absence of social support in the form of health insurance and absence of financial support as fathers' working in private work who are liable to uncompensable working days lost because of frequent visits to health care facilities adding to a financial burden of the already economically compromised households parents.

\section{CONCLUSION AND RECOMMENDATIONS:}

This study concluded that the level of self-care practice for most children with nephrotic syndrome was low. The independent predictors associated with low self-care included frequency of rehospitalization, parents' socioeconomic standard, education and occupation. In regression analysis the more risk predictors in decreasing order were fathers' education, socioeconomic standard and frequency of hospital admission. Self-care level of nephrotic syndrome children should be assessed by the nurse during hospitalization and educational training program should be provided to caregivers of children with low self care to improve disease outcome and minimize re-hospitalization. 
Table I: Distribution of the studied sample according to their general characteristics, causes and duration of illness, number and causes of re-hospitalization

\begin{tabular}{|c|c|c|}
\hline \multirow{3}{*}{\begin{tabular}{|cl} 
Characteristics & \\
Age: & \\
& $6-$ \\
& $8-$ \\
& $10-12$ \\
& \\
Mean + SD & \\
2-Gender & \\
\end{tabular}} & $\mathrm{n}=100$ & $\%$ \\
\hline & $\begin{array}{l}53 \\
20 \\
27\end{array}$ & $\begin{array}{l}53.0 \\
20.0 \\
27.0\end{array}$ \\
\hline & \multicolumn{2}{|c|}{$8.7 \pm 2.29$} \\
\hline $\begin{array}{ll}\text { 2-Gender: } & \\
& \text { Male } \\
& \text { Female }\end{array}$ & $\begin{array}{l}58 \\
42 \\
\end{array}$ & $\begin{array}{l}58.0 \\
42.0 \\
\end{array}$ \\
\hline $\begin{array}{r}\text { 3-Educational level: } \\
\text { Grade 1 } \\
\text { Grade 2 } \\
\text { Grade 3 } \\
\text { Grade 4 } \\
\text { Grade 5 } \\
\text { Grade 6 }\end{array}$ & $\begin{array}{l}35 \\
15 \\
10 \\
13 \\
6 \\
21\end{array}$ & $\begin{array}{c}35.0 \\
15.0 \\
10.0 \\
13.0 \\
6.0 \\
21.0\end{array}$ \\
\hline 4-Residence: & $\begin{array}{l}59 \\
41 \\
\end{array}$ & $\begin{array}{l}59.0 \\
41.0 \\
\end{array}$ \\
\hline $\begin{array}{l}\text { Single } \\
\text { First } \\
\text { Last } \\
\text { Inbetween }\end{array}$ & $\begin{array}{l}13 \\
37 \\
32 \\
18\end{array}$ & $\begin{array}{l}13.0 \\
37.0 \\
32.0 \\
18.0\end{array}$ \\
\hline $\begin{array}{l}\text { 6-Causes of illness: } \\
\text { Genetic } \\
\text { Infection } \\
\text { Unknown }\end{array}$ & $\begin{array}{l}19 \\
30 \\
51 \\
\end{array}$ & $\begin{array}{l}19.0 \\
30.0 \\
51.0\end{array}$ \\
\hline $\begin{array}{l}\text { 7-Duration of illness: } \\
\qquad \begin{aligned}<2 \text { years (short) } \\
2-4 \text { years (middle) } \\
4-6 \text { years (long) }\end{aligned}\end{array}$ & $\begin{array}{l}33 \\
45 \\
22\end{array}$ & $\begin{array}{l}33.0 \\
45.0 \\
22.0\end{array}$ \\
\hline $\begin{array}{l}\text { 8- Number of hospitalization: } \\
\text { One } \\
\text { Two } \\
\text { Three } \\
\text { Four and more }\end{array}$ & $\begin{array}{l}25 \\
40 \\
21 \\
14\end{array}$ & $\begin{array}{l}25.0 \\
40.0 \\
21.0 \\
14.0\end{array}$ \\
\hline $\begin{array}{r}\text { Causes of re-hospitalization: } \\
\text { Relapse } \\
\text { Infections } \\
\text { Both }\end{array}$ & $\begin{array}{l}33 \\
17 \\
50\end{array}$ & $\begin{array}{l}33.0 \\
17.0 \\
50.0\end{array}$ \\
\hline
\end{tabular}


Table 2: Sociodemographic characteristics of the families of the studied children

\begin{tabular}{|c|c|c|}
\hline Items & $\mathrm{n}=100$ & $\%$ \\
\hline \multicolumn{3}{|l|}{ No. of children in the family: } \\
\hline One & 13 & 13.0 \\
\hline Two & 31 & 31.0 \\
\hline Three & 43 & 43.0 \\
\hline Four and more & 13 & 13.0 \\
\hline \multicolumn{3}{|l|}{ Mothers' education: } \\
\hline University and more & 24 & 24.0 \\
\hline Secondary, preparatory and primary & 27 & 27.0 \\
\hline Illiterate & 49 & 49.0 \\
\hline \multicolumn{3}{|l|}{ Fathers' education: } \\
\hline University and more & 29 & 29.0 \\
\hline Secondary, preparatory and primary & 32 & 32.0 \\
\hline Illiterate & 39 & 39.0 \\
\hline \multicolumn{3}{|l|}{ Mothers' occupation: } \\
\hline Fixed work & 20 & 20.0 \\
\hline Part-time & 15 & 15.0 \\
\hline House wife & 65 & 65.0 \\
\hline \multicolumn{3}{|l|}{ Fathers 'occupation: } \\
\hline Governmental & 25 & 25.0 \\
\hline Private * & 66 & 66.0 \\
\hline Unemployed & 9 & 9.0 \\
\hline \multicolumn{3}{|l|}{ Socioeconomic standard: } \\
\hline Lowlvery low & 47 & 47.0 \\
\hline Middle & 27 & 27.0 \\
\hline High & 26 & 26.0 \\
\hline
\end{tabular}

*(manual worker, private office, company, industry )

Part 2: Assessment of self-care and predictors of low self-care practice:

Table 3: Percentage distribution of Self-care levels for the participants regarding their total score and three domains of Orem's self-care:

\begin{tabular}{|c|c|c|c|}
\hline \multirow{2}{*}{} & \multicolumn{3}{|c|}{ Self-care level } \\
\cline { 2 - 4 } & Low & Moderate & High \\
\hline Total score & 51.0 & 30.0 & 19.0 \\
\hline Universal self-care & 43.0 & 42.0 & 15.0 \\
\hline Developmental self-care & 59.0 & 33.0 & 8.0 \\
\hline Health deviation self-care & 36.0 & 40.0 & 24.0 \\
\hline
\end{tabular}


Table (4) Univarete analysis for the predictors of low self care level among participants:

\begin{tabular}{|c|c|c|c|c|c|c|}
\hline \multirow{3}{*}{ Predictors } & \multicolumn{4}{|c|}{ Self care - level } & \multirow{3}{*}{ OR= $95 \% \mathrm{Cl}$} & \multirow[b]{2}{*}{$\begin{array}{c}P \\
\text { Value }\end{array}$} \\
\hline & \multicolumn{2}{|c|}{$\begin{array}{c}\text { Moderate to } \\
\text { high }\end{array}$} & \multicolumn{2}{|c|}{ Low } & & \\
\hline & No. & $\%$ & No. & $\%$ & & \\
\hline $\begin{array}{l}\text { Age group: } \\
\qquad 6- \\
\qquad 8 \text { - } \\
\quad 10-12 \text { years }\end{array}$ & $\begin{array}{l}26 \\
11 \\
12 \\
\end{array}$ & $\begin{array}{l}(49.1 \%) \\
(55.0 \%) \\
(44.4 \%) \\
\end{array}$ & $\begin{array}{c}27 \\
9 \\
15 \\
\end{array}$ & $\begin{array}{l}(50.9 \%) \\
(45.0 \%) \\
(55.6 \%) \\
\end{array}$ & $\begin{array}{c}r \\
0.79(0.28-2.21) \\
1.26(0.47-3.05) \\
\end{array}$ & $\begin{array}{l}- \\
0.65 \\
0.69\end{array}$ \\
\hline $\begin{array}{l}\text { Gender: } \\
\text { - Male } \\
\text { - Female }\end{array}$ & $\begin{array}{l}27 \\
22\end{array}$ & $\begin{array}{l}(46.6) \\
(52.4)\end{array}$ & $\begin{array}{l}31 \\
20\end{array}$ & $\begin{array}{l}(53.4) \\
(47.6)\end{array}$ & $\begin{array}{c}r \\
0.79(0.36-1.75)\end{array}$ & 0.68 \\
\hline $\begin{array}{l}\text { Residence: } \\
\text { - Rural } \\
\text { - Urban }\end{array}$ & $\begin{array}{l}26 \\
23\end{array}$ & $\begin{array}{l}(44.1) \\
(53.8)\end{array}$ & $\begin{array}{l}33 \\
18\end{array}$ & $\begin{array}{l}(55.9) \\
(46.2)\end{array}$ & $\begin{array}{c}r \\
0.62(0.28-1.38)\end{array}$ & 0.34 \\
\hline $\begin{array}{l}\text { Educational class: } \\
\qquad \begin{array}{l}\text { I st } \\
2 \text { nd } \\
3 \text { rd } \\
4 \text { th } \\
5 \text { th } \\
6 \text { th }\end{array}\end{array}$ & $\begin{array}{l}13 \\
11 \\
6 \\
7 \\
4 \\
8\end{array}$ & $\begin{array}{l}(37.1) \\
(73.3) \\
60.0 \\
(53.8) \\
(66.7) \\
(38.1) \\
\end{array}$ & $\begin{array}{c}22 \\
4 \\
4 \\
6 \\
2 \\
13 \\
13\end{array}$ & $\begin{array}{l}(62.9) \\
(26.7) \\
(40.0) \\
(46.2) \\
(33.3) \\
(61.9)\end{array}$ & $\begin{array}{c}r \\
0.21(0.06-0.82) \\
0.39(0.09-1.66) \\
0.51(0.14-1.84) \\
0.30(0.05-1.84) \\
0.96(0.31-2.93) \\
\end{array}$ & $\begin{array}{l}0.04 \\
0.19 \\
0.29 \\
0.17 \\
0.94 \\
\end{array}$ \\
\hline $\begin{array}{c}\text { Disease duration: } \\
<\text { years } \\
2-<4 \text { years } \\
4-6 \text { years } \\
\end{array}$ & $\begin{array}{c}16 \\
24 \\
9 \\
\end{array}$ & $\begin{array}{l}(46.9) \\
(53.3) \\
(40.9) \\
\end{array}$ & $\begin{array}{l}17 \\
21 \\
13 \\
\end{array}$ & $\begin{array}{l}(53.1) \\
(46.7) \\
(59.1) \\
\end{array}$ & $\begin{array}{c}r \\
0.82(0.33-2.02) \\
1.36(0.46-4.04) \\
\end{array}$ & $\begin{array}{l}0.67 \\
0.58\end{array}$ \\
\hline $\begin{array}{c}\text { Birth order: } \\
\text { Alone } \\
\text { First } \\
\text { Last } \\
\text { In-between } \\
\end{array}$ & $\begin{array}{c}5 \\
18 \\
18 \\
8 \\
\end{array}$ & $\begin{array}{l}(38.5) \\
(48.6) \\
(56.2) \\
(44.4)\end{array}$ & $\begin{array}{c}8 \\
19 \\
14 \\
10 \\
\end{array}$ & $\begin{array}{l}(61.5) \\
(51.4) \\
(43.8) \\
(55.6)\end{array}$ & $\begin{array}{c}r \\
0.66(0.18-2.40) \\
0.49(0.13-1.82) \\
0.78(0.18-3.34) \\
\end{array}$ & $\begin{array}{l}0.52 \\
0.27 \\
0.73 \\
\end{array}$ \\
\hline $\begin{array}{l}\text { Frequency of admission } \\
\text { Once } \\
\text { twice } \\
\text { three } \\
\text { Four and more } \\
\end{array}$ & $\begin{array}{c}20 \\
19 \\
7 \\
3 \\
\end{array}$ & $\begin{array}{l}(80.0) \\
(47.5) \\
(33.3) \\
(21.4) \\
\end{array}$ & $\begin{array}{c}5 \\
21 \\
14 \\
11 \\
\end{array}$ & $\begin{array}{l}(20.0) \\
(52.5) \\
(66.7) \\
(78.6) \\
\end{array}$ & $\begin{array}{c}r \\
4.42(1.39-14.10) \\
8.00(2.10-30.42) \\
14.67(2.93-73.33) \\
\end{array}$ & $\begin{array}{l}0.009 \\
0.001 \\
0.000 \\
\end{array}$ \\
\hline $\begin{array}{l}\text { Causes of re-hospitalization: } \\
\text { Relapse } \\
\text { Infection } \\
\text { Both }\end{array}$ & $\begin{array}{c}16 \\
9 \\
24\end{array}$ & $\begin{array}{l}(46.9) \\
(52.9) \\
(48.0)\end{array}$ & $\begin{array}{c}17 \\
8 \\
26\end{array}$ & $\begin{array}{l}(53.1) \\
(47.1) \\
(52.0)\end{array}$ & $\begin{array}{c}r \\
0.84(0.26-2.70) \\
1.02(0.42-2.46)\end{array}$ & $\begin{array}{l}0.76 \\
0.96\end{array}$ \\
\hline
\end{tabular}

OR= odds ratio, $\mathbf{C l}=$ confidence interval, $\mathbf{r}=$ reference group 
Table (5) Univarete analysis for the predictor of low self-care level of the participant's families:

\begin{tabular}{|c|c|c|c|c|c|c|}
\hline \multirow{3}{*}{ Predictors } & \multicolumn{4}{|c|}{ Level of self-care } & \multirow{3}{*}{$\mathrm{OR}=95 \% \mathrm{Ci}$} & \multirow{3}{*}{$\begin{array}{c}\mathrm{P}- \\
\text { value }\end{array}$} \\
\hline & \multicolumn{3}{|c|}{ Moderate to High } & Low & & \\
\hline & No & $\%$ & No & $\%$ & & \\
\hline $\begin{array}{l}\text { Fathers' education } \\
\text { - University and more }\end{array}$ & 27 & $(93.1 \%)$ & 2 & $(6.9 \%)$ & T & \\
\hline $\begin{array}{l}\text { Secondary, preparatory and } \\
\text { primary }\end{array}$ & 11 & $(34.4 \%)$ & 21 & $(65.6 \%)$ & $25.77(5.1-129.06)$ & 0.000 \\
\hline Illiterate & 11 & $(28.2 \%)$ & 28 & $(71.8 \%)$ & 34.36(6.96-169.6) & 0.000 \\
\hline Mothers' education & & & & & & \\
\hline $\begin{array}{l}\text { University and more } \\
\text { Secondary preparatory and }\end{array}$ & 22 & & 2 & $(8.3 \%)$ & & \\
\hline primary & 14 & $(51.9 \%)$ & 13 & (48.1\%) & $11.14(2.19-56.76)$ & 0.001 \\
\hline Illiterate & 13 & $(26.5 \%)$ & 36 & (73.5\%) & $33.23(6.87-160.6)$ & 0.000 \\
\hline Number of children: & & & & & & \\
\hline One & 5 & $(41.7 \%)$ & 7 & $(58.3 \%)$ & & \\
\hline Two & 20 & $(62.5 \%)$ & 12 & (37.5\%) & $0.43(0.11-1.66)$ & 0.21 \\
\hline Three & 20 & $(46.5 \%)$ & 23 & (53.5\%) & $0.82(0.23-3.00)$ & 0.76 \\
\hline$>$ four & 4 & $(30.8 \%)$ & 9 & (69.2\%) & $1.61(0.31-8.32)$ & 0.57 \\
\hline Father work: & & & & & & \\
\hline Governmental & 20 & $(80.0 \%)$ & 5 & $(20.0 \%)$ & $\mathrm{r}$ & \\
\hline Private * & 26 & $(33.3 \%)$ & 40 & $(66.7 \%)$ & $8.00(1.47-43.68)$ & 0.000 \\
\hline Unemployed & 3 & $(39.4 \%)$ & 6 & $(60.6 \%)$ & $6.15(2.05-18.44)$ & 0.01 \\
\hline Mother work: & & & & & & \\
\hline Fixed work & 16 & $(80.0 \%)$ & 4 & $(20.0 \%)$ & & \\
\hline Part-time & 8 & $(53.3 \%)$ & 7 & (46.7\%) & $3.50(0.79-15.58)$ & 0.09 \\
\hline House wife & 25 & $(38.5 \%)$ & 40 & $(61.5 \%)$ & $6.40(1.92-21.34)$ & 0.001 \\
\hline $\begin{array}{c}\text { Socioeconomic standard: } \\
\text { Hiah }\end{array}$ & 23 & $(88.46)$ & 3 & $(12.54)$ & $r$ & \\
\hline Middle & 17 & $(36.0)$ & 10 & $(37.0)$ & $4.51(1.07-18.93)$ & 0.03 \\
\hline Lowlvery low & 9 & (19.1) & 38 & (80.9) & $32.37(7.49-132.0)$ & 0.000 \\
\hline
\end{tabular}

* ( manual worker, privet office, company, industry)

$\mathrm{OR}=$ odds ratio, $\mathrm{Cl}=$ confidence interval, $\mathrm{r}=$ reference group

Table (6): Logistic regression analysis of independent predictors of low self care.

\begin{tabular}{|l|c|c|}
\hline Predictor & P & OR ( 95 \% Cl) \\
\hline - Father education & - & $r$ \\
- University & 0.119 & $6.08(0.63-58.68)$ \\
- Intermediate & 0.02 & $11.26(1.455-87.138)$ \\
- Illiterate & & \\
\hline -Socioeconomic standard: & 0.007 & $36.95(39.2-300.01)$ \\
- Low very low & 0.022 & $12.87(15.32-135.62)$ \\
- Middle & 0.74 & $r$ \\
- High & & $r$ \\
\hline - Frequency of admission & - & \\
- One & 0.067 & $4.03(0.90-17.94)$ \\
- Two & 0.106 & $3.92(0.784-20.63)$ \\
- Three & 0.0 & $34.451(3.93-301.30)$ \\
- Four and more &
\end{tabular}

$\mathrm{OR}=$ odds ratio, $\mathrm{Cl}=$ confidence interval, $\mathrm{r}=$ reference group. 
Appendix: Questionnaire

ممارسة الرعاية الذاتية لأطفال سن المدرسة المصابين بمتلازمة كلوية

\begin{tabular}{|c|c|c|c|}
\hline \multicolumn{3}{|c|}{ 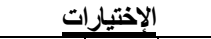 } & الغناصر \\
\hline دائما & أحياتز & لأ & - البعد العام للرعاية الذاتية : \\
\hline 2 & 1 & 0 & 1- 1- يعبش في بيئة مجدة الهواء وخالية من التلوث \\
\hline 2 & 1 & 0 & 2- بشرب اللَّبن على الأقلّل كوب يوميا \\
\hline 2 & 1 & 0 & 3- يشرب على الأقل 6 كوب من الماء يوميا \\
\hline 2 & 1 & 0 & 4- بأكل الأرز وا المخبوزات والدكرونة \\
\hline 2 & 1 & 0 & 5- - يغسل الخضروات و الفو اكه قبل الأكل \\
\hline 2 & 1 & 0 & 6- يأكل الخضروات و الفو اكه متل ( الكرنب / البرتقال / الموز / التفاح / أو الخضروات و الفو اكه الأخرى الأكثر شيوعا ) \\
\hline 2 & 1 & 0 & 7- بأكل اللحوم الييضاء ( السمك و الدجاج ) ( البيض / أو البقوليات) \\
\hline 0 & 1 & 2 & 8- يأكل وجبات خفيفة هتل ( الحلوى او الآبس كريم ) \\
\hline 0 & 1 & 2 & 9- لايتتاول طعام الإفطار ( ينتاسى / يتجاهل ) \\
\hline 0 & 1 & 2 & 10- يأكل القليل من الطعام ( غير اللحم 3 مرات يوميا ) \\
\hline 2 & 1 & 0 & 11- يغسل أسنانه بعد الاستيقاظ في النوم وقبل الذهاب للسرير \\
\hline 2 & 1 & 0 & 12 - يغسل يبيه قبل الأكل وبعد استخدام الحمام \\
\hline 2 & 1 & 0 & 13- يغسل فمه بعد الأكل \\
\hline 2 & 1 & 0 & 14- بأخذ حمام على الأقل مرة أسبو عيا بالثنتاء و3 مرات بالصيف \\
\hline 2 & 1 & 0 & 15- يستخلم الصابون عند الاستحمام \\
\hline 2 & 1 & 0 & 16- يغسل شعره بالثامبو أو الصابون \\
\hline 2 & 1 & 0 & 17- يتبرز يوميا \\
\hline 2 & 1 & 0 & 18- ينام من 8 - 10 ساعات في الليل \\
\hline 0 & 1 & 2 & 19- يثاهد التلفاز أكثر من ساعثين يوميا \\
\hline 2 & 1 & 0 & 20- يمارس أنو اع مختلفة من التمارين البسيطة مثل ( المشى ـ الجرى البطئ \\
\hline 0 & 1 & 2 & 21- يلعب كالعادة مع أصحابه \\
\hline 2 & 1 & 0 & 22- يلبس ملابس تتتاسب مع الطقس او درجة الحرارة \\
\hline & & & || || البعد التنموى للرعاية الذاتية : \\
\hline 2 & 1 & 0 & 23- يتتبع الكثير من أفكار أصحابه \\
\hline 2 & 1 & 0 & 24- يتو اصل مع أصحابه عندما يكون مريضا بالمنزل / المستشفى \\
\hline 0 & 1 & 2 & 25- تقل عدد الأصحاب بعد مرضه أو دخوله المستشفى \\
\hline 0 & 1 & 2 & 26- تعزل نفسك من الأصحاب بعد مرضك أو دخولك المستشفى \\
\hline 0 & 1 & 2 & 27- لاتذهب للمدرسة بسبب إحساسك بالإحر اج من تغير شكل جسك \\
\hline 2 & 1 & 0 & 28- تذهب اللمدرسة أثناء فترة العلاج \\
\hline 2 & 1 & 0 & 29- تؤدي كل واجباتك المدرسية أثثاء فترة العلاج \\
\hline 2 & 1 & 0 & 30- تؤدي واجباتلك المدرسية بمساعدة أثنخاص آخرين عند مرضك في المنزل أو المستشفى ( الأب, الأم, المدره \\
\hline 2 & 1 & 0 & 31 31 هل يلعب الرياضة والألعاب مع أصحابه \\
\hline 2 & 1 & 0 & 32 - هل تناقش واجباتلك أو تتحثث عنها مع أصحابك \\
\hline & & & |||- البعد الصحي الإحرافى للرعاية الذاتية : \\
\hline 0 & 1 & 2 & 33- يأكل طعام كثبر الملح \\
\hline 2 & 1 & 0 & 34- بأكل طعام كثير البروتين ( كالبيض / والسمك / والبقوليات ) \\
\hline 2 & 1 & 0 & 35- هل يذكر و الديه بفحص البول عندما يصاب بققد البروتين في البول \\
\hline 2 & 1 & 0 & 36- هل يرتاح في السرير في فترات التعب / الإعياء/فقد البروتين في البول /و التورم. \\
\hline 2 & 1 & 0 & 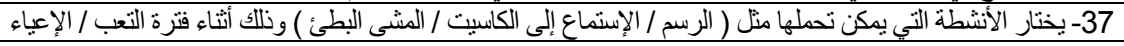 \\
\hline 0 & 1 & 2 & 38- يشارك في الرياضات التنافسية العنيفة \\
\hline 2 & 1 & 0 & 39- هل يتبع إرشادات الممرضة في إختبار ها لنو عية اللعب \\
\hline 0 & 1 & 2 & 40- هل تأخذ الدواء في المو عد المحلد للك \\
\hline 0 & 1 & 2 & 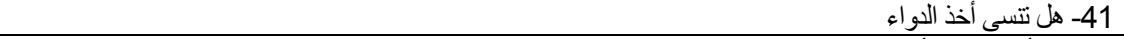 \\
\hline 2 & 1 & 0 & 42 - لا تأخذ الدواء لأنك لا تريده \\
\hline 2 & 1 & 0 & 43- هل تزن نفسك على الأقل مرة شهريا \\
\hline 2 & 1 & 0 & 44- هل تذكر و الديك لأخذك لطيبب الأسنان للفحص الدوري مرتبن سنويا \\
\hline
\end{tabular}




\begin{tabular}{|c|c|c|c|}
\hline 2 & 1 & 0 & 45- تقول لو الديك لأخذك لطيبب الأسنان عندما تثتكي من قرح بالفم / ألم أو إلتهاب \\
\hline 0 & 1 & 2 & 46- هل تذهب| تعبش فى الأماكن المزدحمة ( المنرل, الفصل الدراسى, مكان التزرفيه \\
\hline 2 & 1 & 0 & 47- هل تحدث و الدبك في حالة ظهور علامات و أعر اض جانبية من الدو اء \\
\hline 2 & 1 & 0 & 48 - هل تنكر والديك بأن بأخذوك للمتابعة تبعا للجنول المحدد \\
\hline 2 & 1 & 0 & 49- هل تخبر والديك ومدرسيك في حالة وجود أى أعراض غير طييعية \\
\hline 2 & 1 & 0 & 50- هل تشرب الكثير من الماء أو تَأكل الكثير من الفو اكه في حالة شكو الك من الإمساك \\
\hline
\end{tabular}

\section{REFERENCES}

1- Kyle T. Essentials of pediatric nursing. $6^{\text {th }}$ ed. Philadelphia: Lippincott; 2008.P. 1370-4.

2- Pillitteri A. Maternal \& child health nursing, Core of the child bearing \& child rearing family. $4^{\text {th }}$ ed. Philadelphia: Lippincott. Williams \& Wilkins; 2010. P. 919-22.

3- Klossner NJ. and Hatfield NT. Introductory maternity \& Pediatric nursing. $2^{\text {nd }}$ ed. Philadelphia: Lippincott Williams \& Wilkin;.2010. P. 755-65.

4- Fahmey ME, Fattouh AM, Hegazy RA, Essawi M. ACE gene Polymorphism in Egyptian Children with idiopathic nephrotic Syndrome, Clinical Study. Research institute of ophthalmology. 2008; 109 (7) $298-301$.

5- Eddy AA, and Symons JM. Nephrotic Syndrome in Childhood. Lancet. 2003; 362: 629-39. (PubMed).

6- Doe J, Funk M, Mengel M, Doehring E, Ehrich H. Nephrotic Syndrome in African Children: Lack of evidence for Tropical Nephrotic Syndrome. Nephrol Dial Transplant. 2006;.21: 672-6.

7- Dillion MJ, Reesl et al. The use of steroid sparing agents in steroidsensitive nephrotic syndrome. Pediater Nephrol. 2003; 18: 919-24.

8- Arneil G. Nephrotic Syndrome in children: an overview. Indian Journal of Pediatrics. 2008; 49 (6). 23 - 7.

9- Robert S. Management of Nephrotic Syndrome in children, Health Care
Professionals Home Page. 2005 available at: http: // www.hcplive.come/general Publications / Resident and - staff.

10- Arun P, Ghosal M. Behavior Profile of Children with nephrotic Syndrome. Indian Journal of Psychiatry. 2000;51(2):122-6.

11- Gaffney Kf, Moore JB. Testing Orem's theory of self-care deficit dependent care agent performance for children. Nurs Sci Q. 2001;9:160 - 4.

12- Alligood M R, Tomey A M. Nursing Theory: Utilization \&Application $.3^{\text {rd }}$ ed. Missouri: Elsevier Mosby Publications; 2002.

13- Tomey AM, Alligood. MR. Nursing theorists and their work. $5^{\text {th }}$ ed. Philadelphia: Mosby; 2002.

14- George JB. Nursing Theories: The Base for Professional Nursing Practice $.5^{\text {th }}$ ed. New Jersey: Prentice Hall;2002.

15- World Health Organization. Current and Future Long-term Care Needs. An Analysis Based on the 1990 WHO Study. France Creative Publications. 2002 \{Cited 18 Feb 2006\} Availablefrom URL: http://www.who.int/entity/chp/knowled ge/publications/1tc_needs.pd

16- Tork H. Care dependency among school - age children: Literature review. Nursing and Health Science. 2007; 9. 142 - 9.

17- Fan E. Self - care Behaviors of school 
age children with heart disease. Pediatric Nursing. 2008; 34.

18- Ghuan W, Wen Y, Ning LZ. Psychological status of both children with the nephrotic syndrome or acute glomerulonephritis and their parents. Chinese J. Contemp Paediatr. 2001; 3: $144-7$.

19- Huether S. Alterations of renal and urinary tract function in children. Pathophsiology; the biologic basis for disease in adults and children. $4^{\text {th }}$ ed. St. Louis, Mosby.2002;1212 - 30.

20- Wilson D, Winkestein M. Wong's essentials of pediatric nursing. $7^{\mathrm{ed}}$. Elsevier Mosby.2005; P: 996 - 7.

21- Vogt BA, Avner ED. Conditions particularly associated with proteinuria: Nephrotic syndrome. In Behrman RE, Kliegman RM, Jenson HB, editors. Nelson Textbook of Pediatrics. $17^{\text {th }}$ ed. New Delhi Elsevier India. 2004; p. 1753 - 7.

22- Hogg J, Portman R, Millnar D, Lemley $\mathrm{K}$, Eddy A, Ingelfinger J. Evaluation and management of Proteinuria and nephrotic syndrome in children : Recommendation from a pediatric nephrology panel established at the National Kidney Foundation Conference on Proteinuria, Albuminuria, Risk, Assessment, Detection and Elimination ( PARADE). Pediatrics.2000; 105 (6), 1242 - 9.

23- Artinian, NT Magnan, $M$, Sloan, $M$, Lange. PM. Self-care behaviors among patients with heart failure. Heart \& Lung.2002; 31(3) 161- 71.

24- Hogg RJ, Furth S, Lemley KV, Partman R, Schwatrz G, et al. National Kidney Foundation kidney disease outcomes quality initiative clinical practice guidelines for chronic kidney disease in children and adolescents: Evaluation, classification, and stratification. Pediatrics.2003; 111(6) 1416 - 21.

25- Ruth EM, Landolt MA, Neuhaus TJ, Kemper MJ. Health related quality of life and psychosocial adjustment in steroid sensitive nephrotic syndrome. J Pediater. 2004; 145:778 - 83.

26- Eudman E, Katon W, Bush T, et al. Behavioural factors associated with symptoms outcomes in a primary care-based depression prevention intervention trial. Psychol Med.2003; 33:1326-32.

27- Slusher L. Self-Care agency and selfcare practice of adolescents. Issues Cumpi Pediater Nurs. 2004;22: 49 58.

28- Phlermo T, Childs G, Burgess E, Kauggars A, Comer D, Kelleher $\mathrm{K}$. Functional limitations of school-aged children seen in primary care. Child Care. Health Dev. 2002; 28: 179 - 89.

29- Wong W. idiopathic nephrotic syndrome in New Zealand Children: demographic, clinical features, initial management and outcome after twelve - month follow-up Results of a three-year national surveillance study. J Paediater Child Health. 2007; 43 :337 - 41 .

30- Wong V, Wong S, Chan k, Wong W. The Functional Independence Measure for Chinese children: Hong Kong cohort. Pediatrics. 2002;109:17.

31- ALserety Aw. An educational Program for Mothers of Children with Nephrotic Syndrome. Unpublished PHD Thesis. Ain Shams University. 2003.

32- Wilson D, Hockenberry. Wong's nursing care of infants and children. 8 th ed. Philadelphia: Mosby Elsevier;2007. P.1249.

33- Schmidt C. Mothers' perceptions of self-care in school-age children with 
diabetes. Am J Matern Child Nurs 2003; 28: 362 - 70.

34- Phlermo T, Childs G, Burgess E, Kauggars A, Comer D, Kelleher K. Functional limitations of school-aged children seen in primary care. Child Care Health Dev. 2002; 28: 179 - 89.

35- Lin EH, Katon W, Von Korff M, et al. Relationship of depression and diabetes self-care, medication adherence and preventive care. Diabetes care.2004; 27:2154-60.

36- Fahmy S, ELsherbiny A. Determining simple parameters for social classification for Health Research. Bulletin of High Institute of Public Health, 1983;13(5):95-107. 